\title{
Failures of harbour walls at Malaga and Barcelona
}

\author{
José María del Campo · Vicente Negro
}

\begin{abstract}
The paper describes the failure of harbour walls which occurred at Malaga on 4th July 2004 and at Barcelona on 1st January 2007 , associated with an inadequate consideration of the ground conditions in the light of the marine environment. At Malaga, there was an existing breakwater hence the new harbour was protected from the effect of the waves while at Barcelona, the construction of the quay wall proceeded at a faster rate than the breakwater. In both cases the wharf backfill was placed rapidly on the soft muds, progressing from the inland side. The paper discusses the importance of an overview including the ground investigation, engineering design, construction method and speed of construction.
\end{abstract}

Keywords Bearing capacity - Caissons - Shallow foundations - Failure modes - Study cases

\section{Introduction}

Despite the collapse of the breakwater at Sines, Porlugal on 28th February 1978 related to fluidisation of the armour stone and the liquefaction of the sand supporting the breakwater at New Barcelona Harbour Mouth, Spain on 10 th November 2001 , too often there is inadequate attention paid to the significance of the marine environment. of particular importance are the interplay between ground

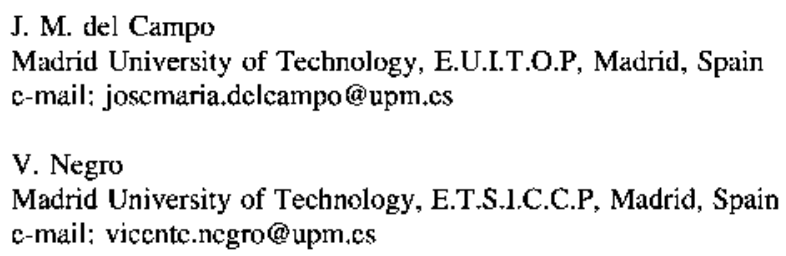

conditions and the base support of breakwaters/harbour walls, the difference between the water flow through these two types of structure, the differential loading on harbour walls and the dynamic effect of the tides/waves.

This short paper presents two case studies. The first involves container quay number 8 in Malaga, southern Spain, and the second the first alignment of the Prat Quay in Barcelona, an inner construction sheltered by the south secondary breakwater. Both constructions were built as gravity, monolithic, reinforced concrete structures using caissons (ROM 0.2/90, Maritime Works Recommendations 1992).

In each case, a thorough geological and geotechnical campaign was undertaken to determine the type of structure and interaction between the ground and the structure. In Malaga the lithological profile was elucidated using boreholes which indicated the presence of a grey more or less clayey mud which varied in thickness but always extended for more than $5 \mathrm{~m}$. Below the mud was a gravel and sand layer up to $10 \mathrm{~m}$ thick which rested on a cemented, hard clay layer (ROM 0.5/94, Maritime Works Recommendations 1994). The natures of the four horizons are given in Table 1 and the parameters adopted for each of the layers in Table 2.

In the Prat Quay in Barcelona, boreholes were also undertaken and the materials making up the sea bed were characterised geotechnically using static penetration tests (piezocones). In addition, data available from the Port Authority (1988-2003) was considered. The boreholes proved five layers: a surface layer of sand which extends to $18 \mathrm{~m}$ below sea level (bsl); a layer of silt varying in thickness between 40 and $50 \mathrm{~m}$; some $5-10 \mathrm{~m}$ of sand and gravel; up to $10 \mathrm{~m}$ of silty sandy clay and a lower stratum of sand. In view of these conditions, a number of possible solutions were considered, including various types of piles, 
Table 1 Geology of the material at the position of the structures

\begin{tabular}{ll}
\hline Depth & Soil description \\
\hline-8 to $-10 \mathrm{~m}$ & Very loose silty sand and sandy silt \\
-10 to $-21 \mathrm{~m}$ & Very soft clayey silt \\
-21 to $-24 \mathrm{~m}$ & Very soft clay \\
-24 to $-26 \mathrm{~m}$ & Grey stones and gravel in a sand and clay matrix \\
\hline
\end{tabular}

Table 2 Parameters used

\begin{tabular}{lllllll}
\hline Level & $1_{\text {'sat }}^{\prime}$ & $\begin{array}{l}c_{\mathrm{u}} \\
\left(\mathrm{t} / \mathrm{m}^{3}\right)\end{array}$ & $\begin{array}{l}c^{\prime} \\
\left(\mathrm{kg} / \mathrm{cm}^{2}\right)\end{array}$ & $\begin{array}{l}\phi^{\prime}\left(\mathrm{kg}^{\circ}\right) \\
\left.\mathrm{cm}^{2}\right)\end{array}$ & $\varepsilon_{o}$ & $C_{e}$ \\
\hline Sandy silt & 1.9 & 0.22 & 0.00 & $10-20$ & 0.90 & 0.30 \\
Silty clay & 1.9 & 0.23 & 0.20 & 29 & 0.97 & 0.22 \\
Clay & 1.8 & 0.20 & 0.20 & 23 & 1.06 & 0.30 \\
Gravel and rip-rap & 2.0 & - & 0.00 & 35 & - & - \\
\hline
\end{tabular}

curtain walls. sheet piling and floating docks but it was decided the gravity section would be built with heavily reinforced concrete caissons on very thick. long rock fill blankets.

\section{Wave forces during construction}

At Malaga, the stricture was protected by a breakwater hence the wave action had no influence on the construction. However, at the Prat Quay in Barcelona, the construction of the quay's first phase coincided with the port's south breakwater extension. As the breakwater was advanced at a slower rate than the quay, for some time the quay was exposed to significant wave forces. As a consequence, a thicker caisson was constructed in the first phase in order to withstand the dynamic wave action. The stability analysis was based on a study of the marine climate, assuming a $2-4$ year period before the south breakwater was effective (ROM 0.0/2002. Maritime Works Recommendations 2002).

$$
\begin{gathered}
T_{r}=\frac{-n}{L n\left(1-P_{f}\right)}=\frac{-4}{\operatorname{Ln}(1-0.10)}=38 \text { years; } \\
T_{r}=50 \text { years }
\end{gathered}
$$

$T_{r}$ calculated storm return period, years: $n$ minimum useful life in construction phase, years: $P_{f}$ probability of failure adopted.

The caisson for the Prat Quay was designed based on the above, using Goda's classical crest (Goda 1985), Sainflou's sine diagrams (Sainflou 1928) and Takahashi's theory (Takahashi 1999), following the geometric indications of Mc Connell's parameter map (McConnell et al. 2000). The results of the analyses undertaken to assess the significance of the waves are reported in Table 3 .
Table 3 Results of analyses undertaken to assess the significance of

\begin{tabular}{|c|c|c|c|c|c|c|c|c|}
\hline \multirow[t]{2}{*}{ Direction } & \multicolumn{2}{|c|}{10 years } & \multicolumn{2}{|c|}{20 years } & \multicolumn{2}{|c|}{50 years } & \multicolumn{2}{|c|}{100 years } \\
\hline & $\mathrm{CE}$ & $\mathrm{LCS} 0 \%$ & CE & $\mathrm{LC} 90 \%$ & CE & $\mathrm{LC} 90 \%$ & $\mathrm{CE}$ & LC90\% \\
\hline ENE & 4.7 & 5.2 & 5.2 & 5.7 & 5.7 & 6.6 & 6.2 & 6.9 \\
\hline E & 4.9 & 5.4 & 5.4 & 6.0 & 5.9 & 6.7 & 5.5 & 7.1 \\
\hline ESE & 5.0 & 5.6 & 5.6 & 6.1 & 6.1 & 6.9 & 6.5 & 7.4 \\
\hline $\mathrm{SE}$ & 4.2 & 4.6 & 4.6 & 5.2 & 5.1 & 5.7 & 5.4 & 6.2 \\
\hline SSE & 4.0 & 4.4 & 4.4 & 4.9 & 4.9 & 5.4 & 5.1 & 5.8 \\
\hline S & 3.4 & 3.8 & 3.8 & 4.2 & 4.1 & 4.6 & 4.4 & 5.0 \\
\hline SSW & 1.9 & 2.1 & 2.1 & 2.4 & 2.3 & 2.7 & 2.5 & 2.8 \\
\hline
\end{tabular}
the waves

\section{Nature of construction}

In addition to the sea states and their dynamic effects on the structures, the use and operating forces and the loads transmitted to the ground by the structures. it was also necessary to consider berthing and mooring manoeuvres. The designers chose different types of structure with different degrees of rigidity which would interact to optimize the facility (BSI. Maritime Structures 1991). Prefabricated. reinforced concrete caissons, various pile types. cantilever wall, curtain wall and floating dock were all considered but both Port Authorities chose gravity caissons with a high volume of concrete.

\section{Malaga harbour container terminal}

Following dredging the structure was founded on an $8 \mathrm{~m}$ thick concrete strip which extended from 15 to $22 \mathrm{~m}$ bsl. The silty mud dredged had a low $\phi^{\prime}$ of ca. $10^{\circ}$. The dredged slope was $1: 5\left(11^{\circ}\right)$ on the exposed side and $1: 7\left(8^{\circ}\right)$ on the landward side.

In order to operate the Terminal on the concession system. the wharf fill was consolidated by loading in $3 \mathrm{~m}$ lifts on the landward side. A standard cross section for the quay is shown in Fig. $I$ and the geotechnical profile in Fig. 2.

The first part of the construction was finished in July 2004 and began operating. although ground improvement and consolidation continued (see Fig. 3). Much of the fill beneath the wharf was placed on mud which had not been fully appreciated at investigation/initial construction stage. As a consequence. five of the central caissons slid outwards, causing the quay wall to fail (Fig. 4). Possible contributory causes include: insufficient dredging of the soft material beneath the wharf area: too rapid a placement of the fill and an inadequate thickness of the support strip. As a consequence of the limited appreciation of the ground conditions at both investigation and construction stages, the project was delayed by more than 12 months for the 


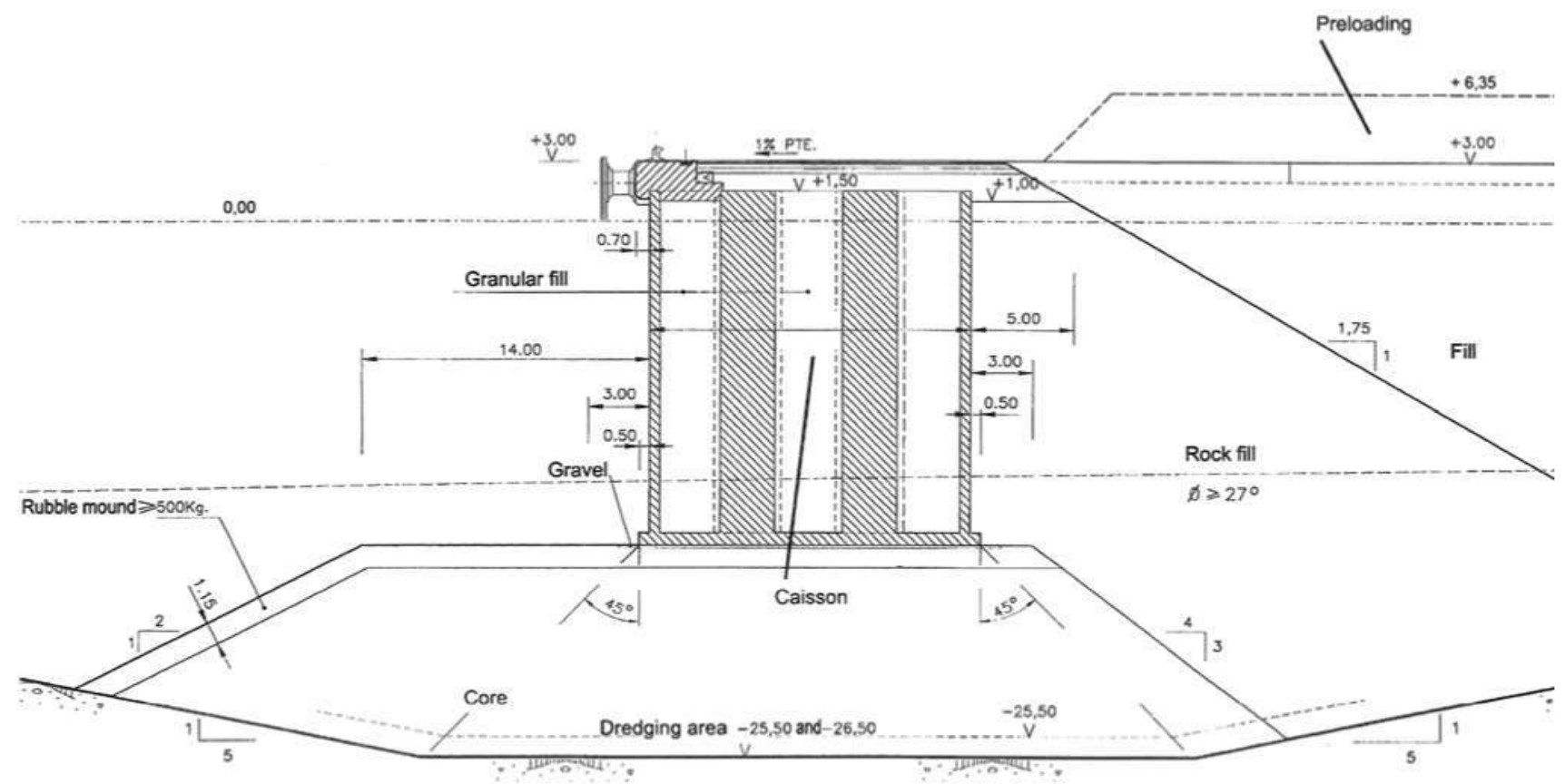

Fig. 1 Standard cross section of the Malaga quay

Fig. 2 Longitudinal profiles along the quay's alignment
Area displaced with approximate $1 \mathrm{~m}$ subsidence

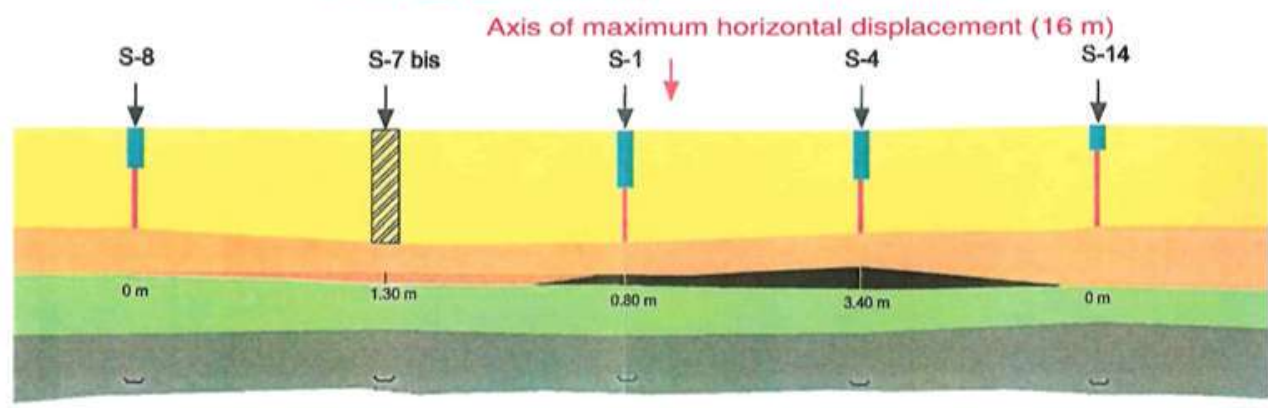

Longitudinal profile along the line of boreholes over the caissons (Profile 1)

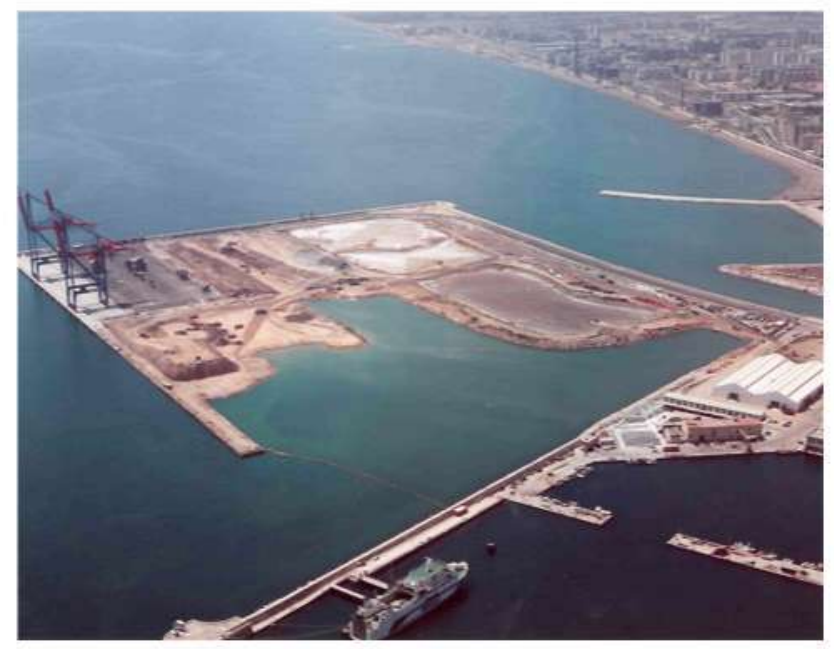

Fig. 3 Malaga quay in the construction phase demolition and replacement of the structural elements (caissons) and foundations.

Prat Quay in Barcelona

The Prat Quay is a $1,500 \mathrm{~m}$ long construction with two sections (I and II) protected by the south extension to the Barcelona breakwater (Figs. 5, 6, 7). Prat I was built after mud dredging from 16 to $25 \mathrm{~m}$ bsl and the placement of a $9 \mathrm{~m}$ thick rock fill blanket. The wall itself consisted of four caissons on granular foundations. During the construction of the second phase, the work was protected by the extension to the sloping breakwater. Following dredging to $24 \mathrm{~m}$ bsl, the $11.5 \mathrm{~m}$ wide caisson was placed on a $8 \mathrm{~m}$ thick rock blanket at a level of $16.5 \mathrm{~m}$ bsl (Negro et al. 2008) (Fig. 8). 


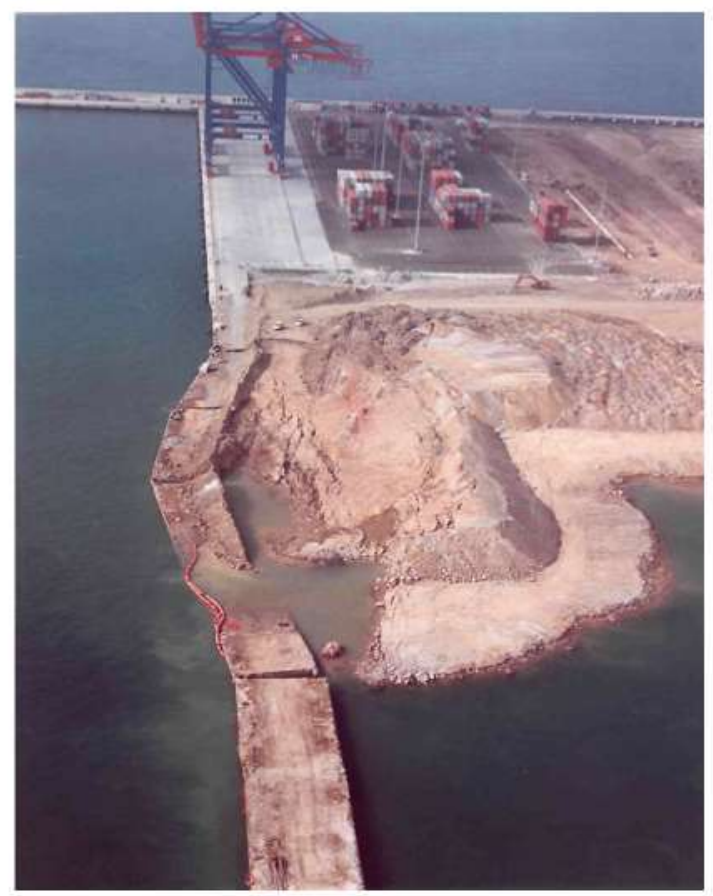

Fig. 4 Deep central core sliding phase

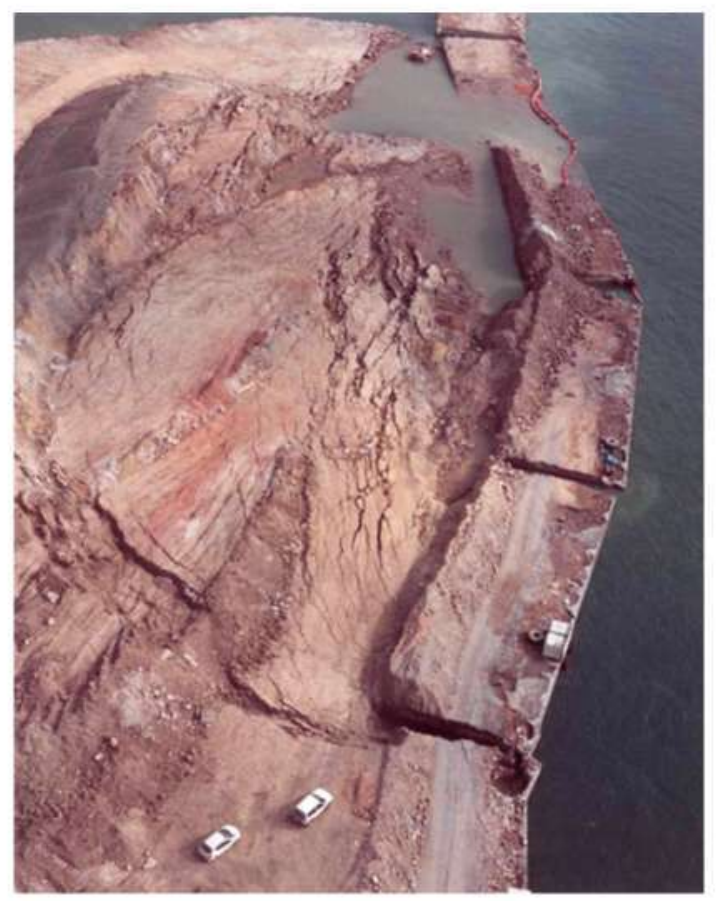

Fig. 5 Collapse of the second phase of the Terminal. East-west aerial view

Some key points of the project include:

1. The first phase was to act as a breakwater while the second phase was protected by the breakwater and hence was designed as a gravity structure.

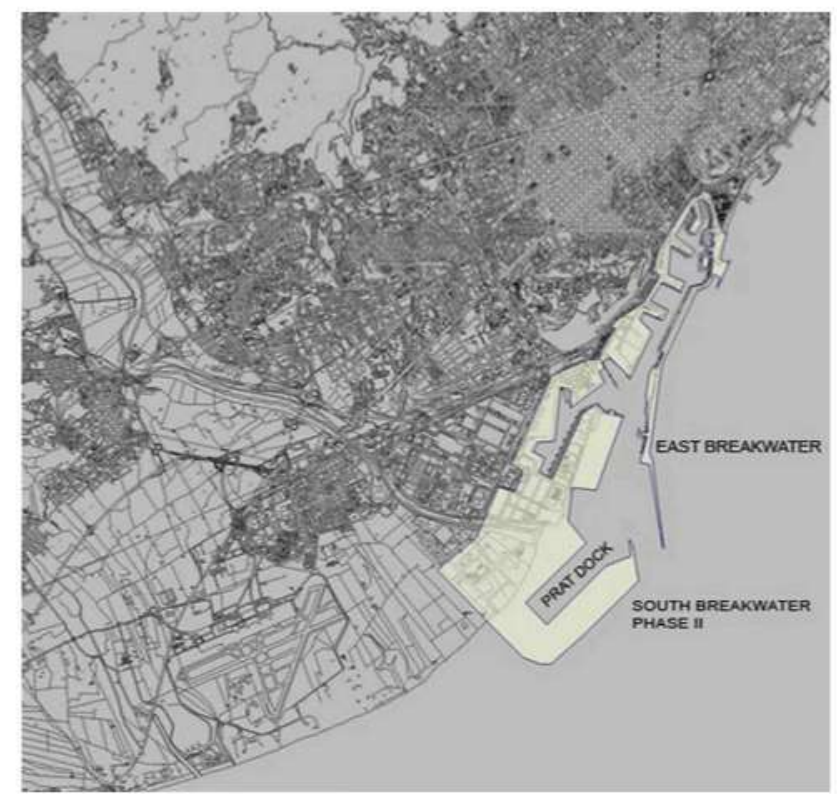

Fig. 6 Barcelona Harbour extension projects, 2005-2015

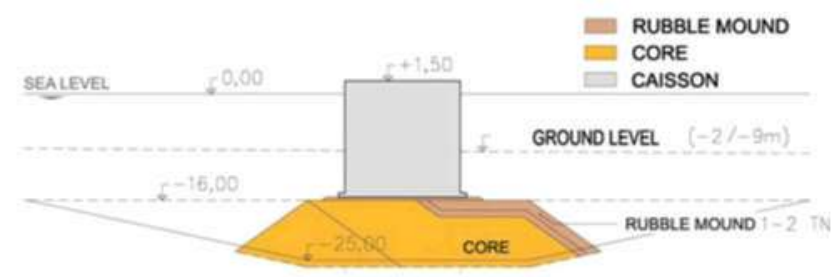

Fig. 7 Typical Prat Quay cross section, first phase (breakwater behaviour)

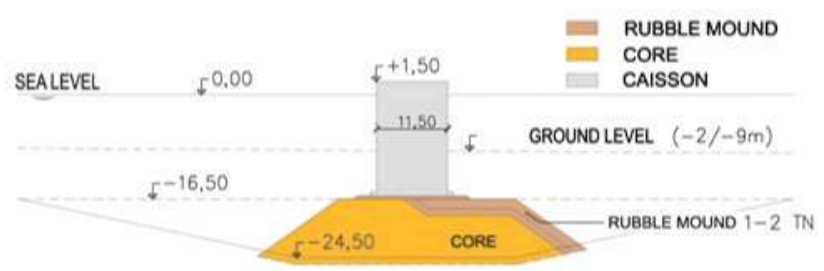

Fig. 8 Typical Prat Quay cross section, second phase (dock behaviour)

2. The phases and the transformation from breakwater to quay, filling, consolidation and paving were put out to tender separately, with a slight time lag.

3. The caisson and fill works were undertaken by different companies and there were different site managers.

4. The nature of the hydraulically placed fill was not adequately studied and it was placed very quickly to meet operational requirements.

5. The fills were placed commencing at the landward side, such that a lake was created inside the new structure.

6. Drain spillways were not provided.

7. In the initial phase, when the structure was built as a breakwater, there was no rear rubble mound, 
(a)
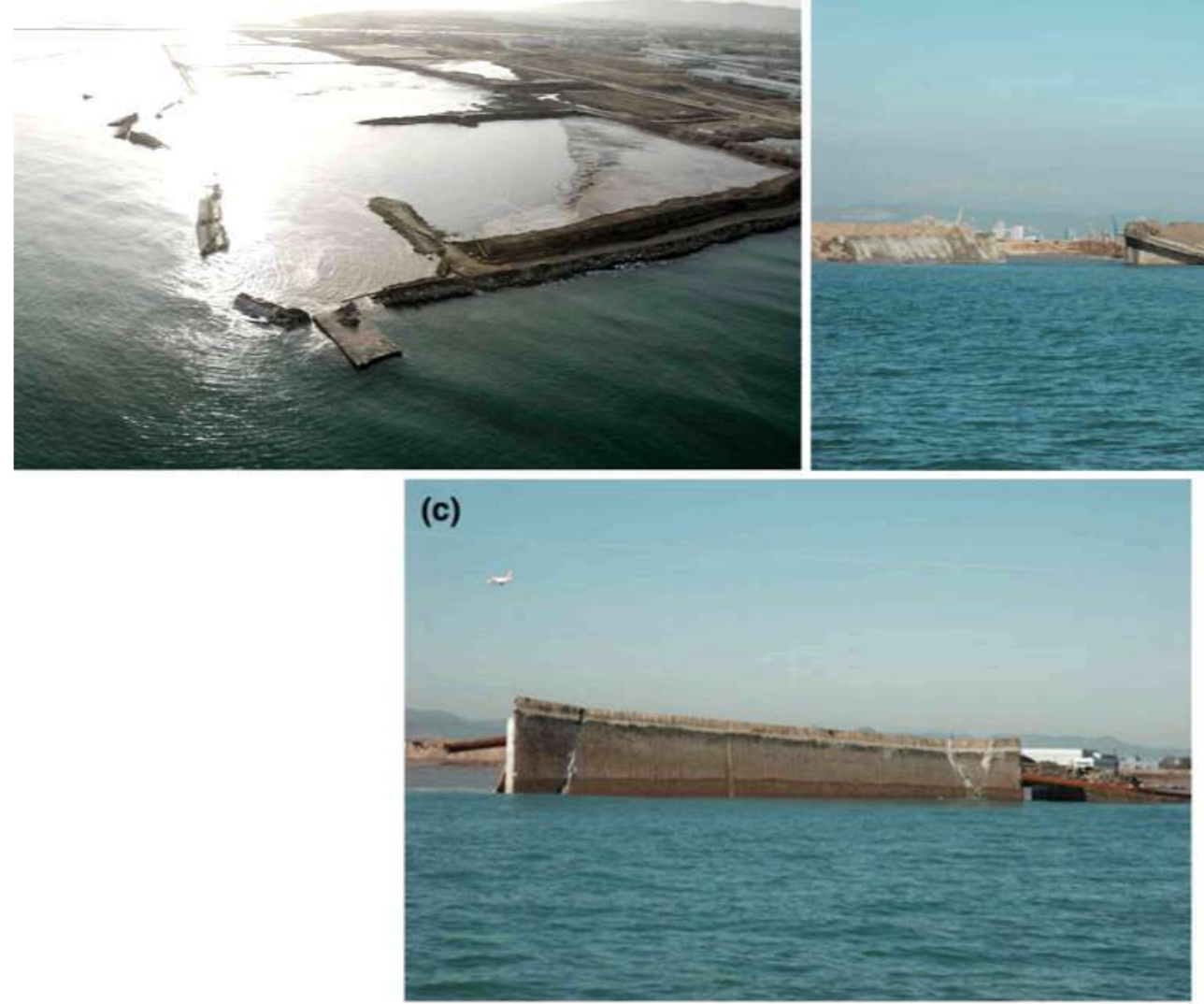

(b)

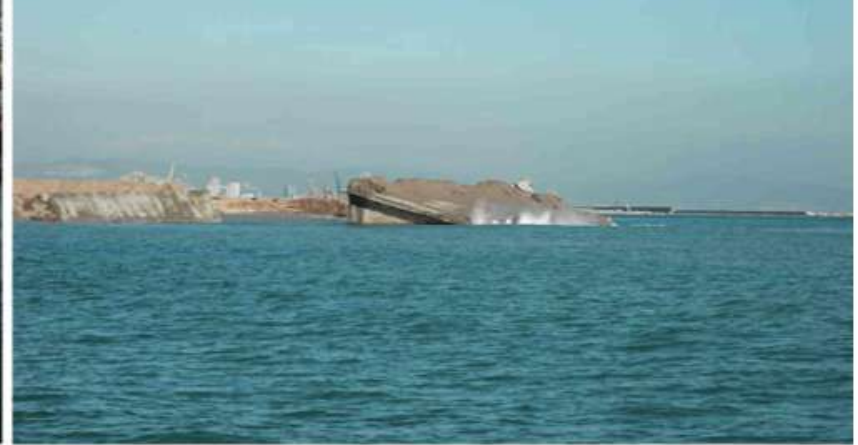

Fig. 9 a State of Prat Quay after the collapse. b State of the caissons after the quay slid. $\mathbf{c}$ State of the caissons after the quay slid

consequently the loading on the monolithic structure was greater than anticipated in the design.

8. The caisson acted as a dam, hence the pressures were higher than anticipated at design stage.

9. The tidal environment, as well as the variable pressure imposed on the structure by waves, was difficult to model.

10. The balance of effective and neutral stresses may cause ground liquefaction and siphoning.

With these limitations, the quay was prone to sliding as a consequence of only a slight environmental, geotechnical or structural disturbance and it collapsed on 1 January 2007. (Fig. 9a-c).

After debris removal, blasting and caisson refloating, repair works were undertaken during 2008 and 2009 and it is hoped the Terminal will come into service in 2010.

\section{Discussion and conclusions}

Construction in a marine environment subjected to alternating stresses requires careful consideration. The brief case studies of the Malaga Terminal and Prat Quay at Barcelona highlight the importance of the following factors.

1. Before using gravity structures in this marine environment, the ground requires improvement or consolidation to ensure adequate geotechnical parameters.

2. The soft material should be removed by dredging and replaced with adequately compacted material.

3. Care must be taken if rapid construction is undertaken as loading too quickly may cause short term stability problems. The construction works should not be compromised by the client's desire to utilise the facility at the earliest possible date.

4. Where gravity walls are used, a rear rubble mound of granular material should be constructed with a slope angle $<37^{\circ}$.

5. An inner construction is interdependent with the linear structure. The containment wall and yard fills cannot be addressed separately.

6. Provision should be made for the removal of water as the fill operation takes place.

7. Analyses should be made not only prior to construction but during all phases of the works. 
8. In a marine environment. demolition and debris removal is always more difficult and hence time taking and costly than on-land works.

\section{References}

Goda Y (1985) Random seas and design of maritime structures. University of Tokyo Press, Tokyo

Maritime Structure (1991) Part 7. Guide to the design and construction of breakwaters. British Standard. BS 6349. Part 7: 1991 . Civil Engineering and Building Structures Standards Policy Committee

Maritime Works Recommendations (1992) Actions in the design of maritime and harbour works. ROM 0.2/90. Ministry of Public Works
Maritime Works Recommendations (1994) Geotechnical recommendations for the design of maritime and harbour works. ROM $0.5 /$ 94. Ministry of Public Works

Maritime Works Recommendations (2002) General criteria. ROM $0.0 / 2002$. Ministry of Public Works. Ports of the State

McConnel KJ, Allsop NWH. Flohr H (2000) Seaward wave loading on vertical coastal structures. Coastal Structures 99. Balkema. Rotterdam

Negro V, Varela O, García Palacios J, López JS (2008) Diseño de Diques Verticales. Colegio de Ingenieros de Caminos, Colección Seinor, No. 26

Sainflou G (1928) Essai sur les digues maritimes verticals. Annales des Pont et Chaussées 98(11):5-48

Takahashi $S$ (1999) Design of vertical breakwater. Breakwater design. Gregory P- Tsinker. Chapman and Hall. International Thomson Publishing 